\title{
The Legitimation of the Albanian Totalitarian Regime
}

\author{
Belina Bedini, MSc. \\ Aleksandër Moisiu University of Durrës, Albania \\ Email: belinabedini@yahoo.it
}

\section{Doi:10.5901/mjss.2014.v5n16p500}

\section{Abstract}

The totalitarian regime in Albania has been considered as one of the most rigid and isolated of the twentieth century, in the whole Eastern Europe from 1945 to 1991. Even though the isolationist ideology has been convenient to support the status-quo of the communist regime, it led to the social-economic crises, and consequently to the collapse of the communism. However, in order to understand the totalitarian ideology and the behavior of its leader Enver Hoxha, it is important to focus on the particular philosophical principles where the regime found the necessary base to legitimate itself. This specific totalitarian philosophy, in the Albanian post- communist literature, is known as "Enverism". Indeed, the totalitarian leader, tried to legitimate his totalitarian power by pretending and propagandizing that the Marxist-Leninist doctrine constituted the only pure truth, and the common good. In one hand, totalitarian leader tried to legitimate the suppression of any kind of resistance against the totalitarian project. On the other hand, the citizens obeyed to the regime, because they believed that this project would be the embodiment of the pure truth and the common good. This paper will analyze the Albanian dictatorship ideology as an instrument of legitimating. Therefore a strong base of study will be the communist literature that was used as a propaganda instrument. It is significant the fact that the Albanian dictator has published hundreds of books as an author and other hundreds have been published by the Institute of the Marxism Leninism Studies, that was an exclusive propaganda tool of the dictatorship. Through the methodology of the literature review, the paper will try to find out how the E. Hoxha and his oligarchy could justify the choice of communism, but which is more important, how could they stand this regime for almost a half century. In the end the paper will try to answer to the research question: was Enverism a peculiar product of some social, political and historical circumstances?

Keywords: Legitimation, Albania, Dictatorship, Totalitarism, Enverism, Communism

\section{The Establishment of Communism in Albania}

During the early years of the XX century Albania was the only state in the Balkan without a Communist Party. In fact, during the Second World War, there wasn't a dominant political group. The fascism was weak because of the Italian occupation (1920 and 1939), and the land owners where skeptic about the communists' planes. Nevertheless, there were only some unorganized communist groups composed of students and intellectuals in the South of the country. Under these conditions the leader of the Yugoslavian communist party, J. B. Tito, after the German attack on Russia, in accordance with the instruction of Comintern, ${ }^{1}$ sent in Albania two representatives (M. Popovic and D. Mugosha) in order to elaborate the program and the first resolution of the Albanian Communist Party (Vickers, 2008). The Yugoslavian contribution has been recognized and their influence has been considerable up to the end of the Second World War.

The communists assumed the merit of the war for the liberalization of the country in 1945, and took the responsibility to build the new Albanian popular democratic state, under the ideology of the popular democracy. As happened in all the Eastern Europe, also in Albania the regime followed the model of URSS.

Anyway, the first elections have been organized openly (not in ballots), but they were propagandized as democratic, because of the general suffrage that was applied for the first time in the history of Albania (Instituti $\mathrm{i}$ Studimeve Marksiste Leniniste, 1955). In the beginning the communists created a democratic government where the free of organizing, the free of expression, the free of the religion and vote, were provided by law (Instituti i Studimeve Marksiste Leniniste, 1955). However, one year later, in accordance the dispositions of the first constitution (1946), the Parliament lost its sense of the representativeness. Based on this constitution the laws were supposed to be elaborated firstly by the Presidium (the core committee) of the Parliament, that in fact was a party's structure, and after that, in a formal way they could be voted in the assembly sessions. Usually the assembly sessions of the Parliament were organized only twice a year (Krasniqi, 2009).

${ }^{1}$ Abreviation of "Communists International Organization", a communists organization initiated in Moscow during March 1919 


\section{The Characteristics of the Albanian Totalitarism}

The views, opinions and perspectives have always been in accordance with the so called Marxist-Leninist ideology. The Albanian philosopher Artan Fuga, argues the Albanian totalitarianism represented the purest case of the Red Army Weapons. Nevertheless, it was created and grown up with some peculiarities (Fuga, 1998), where we can distinguish four important elements that constitute the Albanian doctrine (Fuga, 1998) (the Enverism)2: a) The leading role of the Albanian Labor Party, ${ }^{3}$ throughout the country life which means that the party was above everything else. Therefore the communists were considered experts of every policy, of every field of life and they enjoyed privileged and high position within the state structure and society; b) The total politicization of the legislative, executive and judicial power and the unification of the power, which means that the major decisions on the state activities were taken by the Political Bureau, ${ }^{4}$ as the highest administrative and strategic unit of the state's administration; c) The centralization of economy or the planning of everything in the economy. In addition, it was implemented the nationalization of every country's assets and of every capital or private property. Since the first constitution the state has been the director of the economy, which was based on the state ownership of industry and of agriculture, and general control of all the sectors of the economy (agriculture, industry, trade and services). The state became the only owner of any kind of capital, like factories, land, houses, apartments; and d) The total indoctrination of the society which produced a uniformed community. The Party was competent in taking decisions concerning life style, marriages and betrayals, the hair and dressing style. Especially, it was forbidden to keep long hair, beard or mustache, because it was considered a deviation from the Marxist-Leninist individual.

The absolute isolation was another peculiarity of the Albanian regime. It started in 1948 when was decided the complete distance from the Yugoslavia (Kasoruho, 2006) and was completed when Albania was retired even from the Warsaw Treatment in 1969. The justification for the isolation was that Yugoslavia, URSS and China were deviating from the pure Marxism-Leninism ideology, because they applied some moderate changes in the implementation of the socialism. Therefore, it was broke every international relationship between Albania and the so called revisionist/imperialist countries. ${ }^{5}$ In this way, Albania was the only country worldwide that was not deviating from the Marxism - Leninism line. Hoxha openly argued that Albania would be the adequate state that could develop the biggest communist revolution.

The religion was substituted by the ideology, which was installed at the center of the society (Ngjela, 2011). At the other hand, the state power was trying to create an ideological man, which can be compared with the religion imposed during the middle age in Europe (Ngjela, 2011). Hoxha emphasized the importance of spreading of the socialist culture and of the Marxist-Leninist ideology, towards the laboring masses because, these doctrines were supposed to compose the true science of the society development (Hoxha, 1974). Moreover, it was highlighted that the ideological education issues, would be considered as an issue of the bread and food (Hoxha, 1974). During the entire regime, it was an ordinary practice that everybody, independently from the profession or working activity, was obligated to attend school or courses on the Marxism-Leninism. These courses usually were organized in different locations like in schools, in factories, in villages etc.

It is important to point out that the base of the Albanian ideology was the labor masses. The state was identified with the class of the workers and peasants, letting outside the intellectuals, that logically are the human capital of every society (Constitution of Albania, 1946). The political elite took a clear distance (almost described as a phobia) from the intellectual elite, but also from the middle class and even more from the further aristocratic class. Considerable components of these categories have been persecuted, imprisoned and eliminated, and mostly with some trite accuses. In reality, even the members of the communist oligarchy, in most of the cases, were not graduated from universities and typically had origins from the villages and from unknown families (Fevziu, 2011).

\section{The Elements of the Legitimation of the Regime}

Totalitarianism, first of all is a certain world view. Indeed, before appearing in prison version, concentration camp or police control, the totalitarianism represents an opinion, because it is expressed through a particular social matrix. It constitutes an invention and a justification of a certain structure of the truth. Therefore the totalitarian thoughts represent a structure of understanding the world and the society (Fuga, 1998). The same thoughts have been embodied even by the Albanian

\footnotetext{
2 Enverism derives from the name of the dictator Enver Hoxha

${ }^{3}$ The Party of Labor was the Communist Party and it was the only political force allowed in the political arena

4 Political Bureau was the head structure of the Communist Party

${ }^{5}$ Everytime there was a new enemy, it was nominated "imperialist" or "revisionist"
} 
totalitarian regime. But, these thoughts have been immediately transformed into the dominant ideology of that regime, the so-called Marxism-Leninism. This dominant ideology was necessary to legitimate the power of the society, but also to legitimate every action taken by the state like the centralization of the economy, the isolationist foreign policies, the politicization of the justice and of the media, the elimination of objectionable individuals and the continuous terror exercised. Hence, as Fuga assumes, the ideology tended to become unmistakable (Fuga, 1998).

However, in order to understand the legitimation of the totalitarian ideology and the behavior of the dictator Enver Hoxha, it is important to focus on the exclusionary logic: a statement is false or true, hence there isn't a third alternative or assertion. As Fuga argues, exclusionary logic can be an explanatory tool of the totalitarian leadership behavior, as long as all the opponents were physically eliminated and the totalitarian idea (centralization of economy, power and justice) could dominate for approximately a half century.

The dictator legitimated his totalitarian power, by pretending and propagandizing that the Marxist-Leninist ideology constituted the only pure truth, and the common good. Consequently Hoxha has considered himself as an impersonator of the absolute truth; instead his opponents have been categorized as the only culprit. Indeed, this logic has been useful to legitimate the regime, but at the same time to constitute the cult of the individual: Enver Hoxha. Furthermore, Hoxha under political doctrine proclaimed that there was no God to believe in, because the only trustful and legitimated God was him, Enver Hoxha as the best follower of Marxism-Leninism ideology.

The choice of Marxism-Leninism was also legitimated through a unique interpretation of the historical facts. At the official History of the Party of Labor is explained that the Albanian democrats, inspired by the very difficult and suffered history of the Albanian people, were forced to choose between the two antagonistic ideologies: the imperialism of the West or the socialism of the East. They choose the second one and as a consequence Albania was attached to the international movement of communism (Instituti i Studimeve Marksiste Leniniste, 1955). This decision was justified as follows: firstly, the URSS in 1925-1930, was successful in the building a strong economy based on industry and agriculture, while the Western countries were still facing the economic depression's effects of 1929; secondly, as a result of the economic crises most part of the western countries supported the fascism and nationalism, like the Fascism in Italy, the Nazism in Germany (Instituti i Studimeve Marksiste Leniniste, 1955); thirdly, the well known intentions of Italy towards the country, were obvious (especially after the Italian invasion in 1939); fifthly, the country suffered from terrible economic conditions under the regime of the King Zogu I, which approached a capitalistic economy during his direction (1928-1939); sixthly the social revolution was supported by people, because the bourgeoisie have strongly collaborated with the Italian Fascism and German Nazism during the Second World War (Akademia e Shkencave, 1983).

Based on these facts the communists could define themselves as the Albanian leaders in the war against the fascism, against the capitalism, against the invaders in the defense of the democratic rights, with the sublime purpose to improve the Albanians' life. Indeed, having in consideration the low standard of living in Albania after the Second World War, the society and the country in general, achieved a considerable development under the regime, like in education, in health care, in infrastructure and economy growth, in sides, industry and agriculture. Based on these facts, the dictator assumed himself as a hero of the new Albania's era. In addition, the whole political class was considered as the representative of an integrated tradition composed of patriotism, innovation, development in one side, and the Marxism in the other side. In this way, E. Hoxha not only obtained the main idea of the legitimacy within the country, but also could justify the external isolation of it (Feraj, 2006).

\section{The Enverism as a Particular Ideology of the Communist Bloc}

The Communist Party, which was transformed in the Party of Labor in 1948 in its $9^{\text {th }}$ Plenum, classified itself as a party under an ideology that does not derivatives from any Albanian tradition. However, enverism tried to give nationalist' shade to its doctrine. This was evident through the responsibility that the regime took, in order to defend the Albanian population outside the official borders of the country, like for example in Yugoslavia (Hoxha, 1982). With this technique, enverism became a cosmopolite and universal ideology, the basing idea of which was the building of a society without national or class' differences.

Socialism was imagined as an ideal system that could solve every kind of conflict, in and out of the state and of the nation. The main idea was the building of a society where everybody could be equal to the other, and where everybody is directly connected to the state (Feraj 2006).

The theoretical frame the enverism was based on the socialistic ideology, assuming for socialism a model of society where the individual issue does not exist, where the state is working for the common wealth or the common good, on which the total control of the society is justified (Leackok, 1906). It is a model of social-economic system based on community, on coöperation, on equality, and on common ownership (Heywood, 2007). Actually, the socialism of Stalin, 
established in Russia was the base of the socialism in Albania (Feraj, 2006). Enverism was a total phenomenon that could involve of all the life's aspects (Feraj, 2006).

The Soviet Union together with the Communist International Movement was understood as the natural defender of all the subordinated people of the word, where Albania was supposed to take part (Instituti i Studimeve Marksiste Leniniste, 1955). As officially confirmed in the statute of the Communists Party, Enverism was in all the effects a socialist ideology, with the purpose to build a socialist system. ${ }^{6}$

Enver Hoxha defines himself as a Stalinist, a follower of Stalin, assuming that Stalinism was the only resource of his theory thinking (Feraj, 2006). Indeed, when after the death of Stalin, the Stalinism was abandoned in Russia; Enver Hoxha didn't hesitate to cut down all the connections with URSS, in despite of the economic dependence of the country and the suffering from a deep economic crisis.

Like generally happened in all the totalitarian regimes, also in the foundation of the enverism ideology was the strategy of terrorism. In accordance to the statistics there are about 700.000 people killed and imprisoned in a population of 1.2 million of people in 1945 and 3.2 million in 1990 (Krasniqi, 2009). Prisons and concentration camps have been built. The political opponents were classified as invaders' collaborators, and have been executed. Mostly in this category were included people with influence like intellectuals, well educated exponents or people graduated abroad, well known families' members. The intention was to use them as an example for the rest of the population. Anyway, massive arrests have been avoided, in order to not terrify people (Fevziu, 2011).

A special attention was given to the youth as an instrument for the revolutionary movement. Hence the youth was considered the main force in the society, that could be ready to transform the society, but only with a strong collaboration with the labor class (Hoxha, 1986). From the constitutional point of view the base of the political power was the simple workers and the village people organized into popular forums (councils) of the cities and of the villages. They could choose their representatives in these forums between the members of the Communist Party (Jacque, 2004). In different literature of the dictatorship, is strongly emphasized that the alliance between the class of workers and peasants, composed the foundations of the popular democracy of the new era (Akademia e Shkencave, 2007). The next Constitution approved in 1976, was highlighted the idea of the "new man", which means the new ideological man. Therefore, to achieve the construction of the "new man" it was necessary a wide ideological and cultural activity, inspired by the Chinese Cultural Revolution (Krasniqi, 2009).

The most important peculiarity of the enverism was the interpretation of the reality, in accordance with the interests of the regime. For instance, the religion was abrogated and it was justified, by the fact that the Albania has a mixed religious population, composed of Muslims, Catholics and Orthodox, that could in some way or somehow, represent a factor for the disintegration of the society (Feraj, 2006). In addition, Hoxha made reference to the Albanian Renaissance Movement, that in order to integrate the population for the independence of the country, was appealing to be strongly focused to the common national characteristics and not on the particularities of the different religions. Actually, during all the history of Albania, from the antiquity to now days, the three religions have always leaved in peace and well understanding. But the Albanian Renaissance Movement was emphasizing the national characteristics instead of religion ones, because often the foreign invaders tried to find support in the religion communities present in the country, for instance Italians to the catholic community, Greeks to the orthodox community or Turkey to the Muslim community, but not because the three communities could have any conflict or contradiction.

Moreover, for providing a strong integration around the regime, was always emphasized, the danger of an attack, or some kind of invasion of the Western countries towards Albania. For this reason a considerable number of military units have been constructed all around Albania. This philosophy was useful also as an instrument, to make people to believe that socialism was the only right way. The Americans and the capitalists in general, were defined as imperialists, like countries that were looking forward to occupy other countries, in order to find markets for the multinational companies (Instituti i Studimeve Marksiste Leniniste, 1955). Sometimes the danger was supposed to come from any alley between the USA and URSS. In accordance with the Hoxha's scenario, the URSS under the direction of Khrushchev was not maintaining an antagonistic position towards the USA, but in contrary, they were alleys that helped each other for building their supremacy all over the globe (Hoxha, 1986).

In accordance to Hoxha, Albania has been always in danger from western enemies (like USA) but also from the internal enemies, like for example the Russian specialist that were working in Albania for assisting the development of some industrial fields like in oil industry, army industry, etc (Hoxha, 1986). In this way he tried to make a stronger unification of people around himself and around the party.

On the other hand, the conflict with URSS was used to justify the economic crises, which came as a consequence

${ }^{6}$ Statuti i Partisë së Punës së Shqipërisë, The Statute of the Albanian Party of Labor 
of some big, unnecessary, irresponsible investments in the heavy industry. Again, Hoxha could legitimate this crisis with the sacrifice that the population was supposed to effort in order to become economically independent from external enemies (Hoxha, 1980).

The whole regime was constructed around the cult of Enver Hoxha that covered different important political and state position at the same time like: prime minister, minister of two or more ministries, commandant of the army and the head of any party's organization, constructing in this way the cult of the individual (Krasniqi, 2009). His portrait was hanging almost in every public place like shops, schools, offices. He was also printed on the coins and currency. In his official pictures, often was surrounded by children in schools, by farmers in the villages, by the mine workers in the mines, etc. He could disseminate a profile of a unique combination of delicate behaviors of a distinguished professor and of a hero (Jacque, 2004).

But, Hoxha also tried to give an international dimension to his profile. Hence he didn't hesitate to declare himself as the hero of the entire population of the Mediterranean, where he described his aim to stumble the URSS to form an army marine base in the gulf of Vlore (South of Albania). In accordance to Hoxha, the Russian intention was control all the Mediterranean Sea from Bosphorus Sea to Gibraltar. As Hoxha have published in his memories, he would never permit the starting of a new war from the Albanian territory that could damage and invade other populations (Hoxha, 1982). After the 70's when Albania interrupted the relations with the rest of the world, including even the communist countries, Hoxha was pretending to take a position of neutrality and wisdom, staying away from the Cold War, assuming that USA and URSS together were trying to cause an unfair war, in favor of their own interest. Based in this logic they were trying to create some influences zones, in order to secure good economic positions, on the damage of other populations (Hoxha, 1986).

\section{Enverism as a Peculiar Product of Some Social, Political and Historical Circumstances}

In this paper, we could have a general picture of the peculiarities of the Albanian dictatorship. It was a system that was based on the Russian model of socialism and stayed loyal to this system, even when URSS and other states of the communist bloc, implemented some moderate changes to the socialist ideology. This was the reason why the regime in Albania became so isolated from all the rest of the world.

Hundred of books have been published during the regime, under the directions of the Institute of Marxism Studies. Some of these books have as author Enver Hoxha. There are books about the relations with URSS, China, Yugoslavia, books on the war for the independence, books on the culture, books on the science, books on the education, books on the youth, books on the agriculture. They are written with a simple and understandable language, in order to be understandable from all the levels of the society. Basically their content is an original interpretation of the historical facts and happening, in favor of the socialism, of the enverism, or against the Western countries. Finding or creating the right interpretation of the history, and serving it in such a simple and understandable way, is a rare characteristic of the enverism.

Anyway the legitimation of the enverism was also helped by the historical circumstances. Unfortunately, in period previous to the communism establishment, Albanian population never had a real democracy experience, that could create a national memory. The only pretended democracy was during the King Zogu I, but it was under disastrous economic conditions that in the end led the country under the Italian occupation. This period of history, was not pleasant to make reference for the Albanian people.

The social conditions couldn't create a conscious society in able to understand the political regime, the human rights or the economic prosperity. Only a little portion of the society was able to read and write, or have some modest education. As explained above the few intellectuals have been immediately eliminated in the framework of the terror and fear disseminated by the regime.

The cult of Enver Hoxha is a special case. He was in the centre of the state and of the society. He was the hero of the development and prosperity. He was not only proclaiming himself as the rescue of Albania, but also as a hero in an international level. For example, at the session of UNO in 28 June 1967, the Albanian government was asking why the American Army and the Soviet Army were located in the Mediterranean Sea. It was not necessary because France, Italy, Greece were enough strong to protect their shores, and which was more, they were part of the NATO. In accordance to Enverism the URSS and USA were just playing a theatre for the entire world, because they were not enemies but alleys, which were collaborating together in a strategy against the little states, like Albania. In the end of the declaration the Albanian government didn't hesitate to shout to the entire world that the Albanian was not terrified by the isolation. Albanians could win against Italian and German fascism, and they can be heroes of Vietnam, Congo, Cuba, Pakistan, Latin America, in other words the hero for all the subordinated people of the world (Hoxha, 1985). 
The "rescue" philosophy was reflected in the same time at the internal politics towards the ethnic minorities. In this way, Hoxha could create a respectable image of the human rights. Hoxha's doctrine approached a peace and respectful policy towards the Greek minority population that was living in the South of Albania. Hoxha has always been very careful in fulfilling all the political, civil and cultural rights of this population (Hoxha, 1985).

On the other hand, Hoxha interpreted the friendship between USA and Latin American States as a case of abuse from USA towards these states. In accordance to Hoxha, the Latin American states that have established economic relations with USA could benefit few investments for in their countries, but these investments couldn't provide a sustainable development. They have only transformed these countries as inputs resources for the American industries (Hoxha, 1985).

At the same time, enverism was the defender of the Albanian culture, history, art. Even the clear anti religion doctrine, the dictator highlighted the importance of the conservation of the paints of the churches. He emphasized the importance of the development of the archeology in order to find out and to protect the antic origin of the Albanian culture. Anyway his preferences were towards the studying of the folk culture (songs, traditions, dialects, poems, myths) in order to contribute in the development of the authentic tradition of the Albanian people (Hoxha, 1985).

In the end we can conclude that Enverism was strongly deriving from Marxism - Leninism, but during its existence, it overcame the pure model of socialism. It was the only state in Eastern bloc that abolished the religion that was totally isolated in the international arena, that never approached and little deviation in the economic implementation of socialism.

Enverism was an all inclusive ideology, because it was assumed to be a doctrine in the defense of the Albanian population in and outside the borders; of the people all over the world that was suffering from the unfair politics of the imperialism; of the ethnic minorities. In the same time enverism was assumed to be a doctrine of all inclusive knowledge, as it took the responsibility to be the centre of all the disciplines like, history, art, music, culture, exact sciences, social sciences, education. In addition Enverim was the doctrine that included all categories of the society the military, the children, the women, the youth, the peasants and especially to the workers. Sarcastically the prisons were full of innocent and brilliant people unfairly accused, punished and in the worst of the cases, physically eliminated.

\section{References}

Akademia e Shkencave e RPS të Shqipërisë. (1983). Historia e Shqipërisë (The History of Albania). Tiranë: 8 Nëntori Akademia e Shkencave. (2007) Historia e Popullit Shqiptar (History of the Albanian People) Tiranë: Toena Feraj, H. (2006). Skicë e Mendimit Politik Shqiptar (Design of the Albanian Political Thought). Tiranë: Pegi

Fevziu, B. (2011). Enver Hoxha, E para Biografi Bazuar në Dokumentet e Arkivit Personal dhe në Rrëfimet e Atyre që e Njohin (Enver Hoxha, The First Biography based on the Documents of the Personal Archives and on the Confessions of those who Have Known). Tiranë: UET Press

Fuga, A. (1998). Shtigje drejt Guvës së Gjarprit. Mbi filozofinë e Sistemeve Politike (Paths Towards the Snake's Cave. On the Philosophy of the Political Systems). Tiranë: Ora

Heywood, A. (2007) Political Ideologies, an Introduction. Wales: Palgrave Macmillan.

Hoxha, E. (1974). Mbi Edukimin Marksist-Leninist të Kuadrove, të Komunistëve dhe të Masave (On the Marxism Leninism Education of the Officials, Communists, and Massive). Tiranë: 8 Nëntori

Hoxha, E. (1980). Hrushovianët Kujtime (Hrushovians Memories). Tiranë: 8 Nentori

Hoxha, E. (1982). Titistët (The Titists). Tiranë: 8 Nëntori

Hoxha, E. (1985). Dy Popuj Miq (Two Friendly Nations). Tiranë: 8 Nentori

Hoxha, E. (1986). Imperializmi dhe Revolucioni (The Imperialism and the Revolution). Tiranë: 8 Nëntori

Hoxha, E. (1986). Superfuqitë Ditar Politik (The Superpowers, a Political Diary). Tiranë: 8 Nëntori

Instituti i Studimeve Marksiste Leniniste. (1955). Historia e Partisë së Punës së Shqipërisë (History of the Party of Labor). Tiranë: 8 Nëntori

Jacque, E. (2004). Shqiptarët (Albanians). Tiranë: Kartë e Pendë

Kasoruho, A. (2006) Un Incubo di Mezzo Secolo (A Nightmare of a Half Century). Lecce: Besa Editrice

Krasniqi, A. (2009). Sistemet Politike në Shqipëri (Political Systems in Albania 1912-2008). Tiranë: Ufo Press

Kushtetuta e Republikës Popullore të Shqipërisë 1946 (The Constitution of the Popular Republic of Albania).

Ngjela, S. (2011) . Përkulja dhe Rënia e Tiranisë Shqiptare 1957-2010. Refleksione për një kohë (Bending and Brake of the Albanian Tiranny 1957-2010. Reflexions for a Period of Time). Tiranë: UET Press

Vickers, M. (2008), Shqiptarët, një Histori Moderne (Albanians: A Modern History). Tiranë: Bota Shqiptare 